\title{
The devil as (convicted) prosecutor: Some ideas on the devil in 1 Peter and Hebrews
}

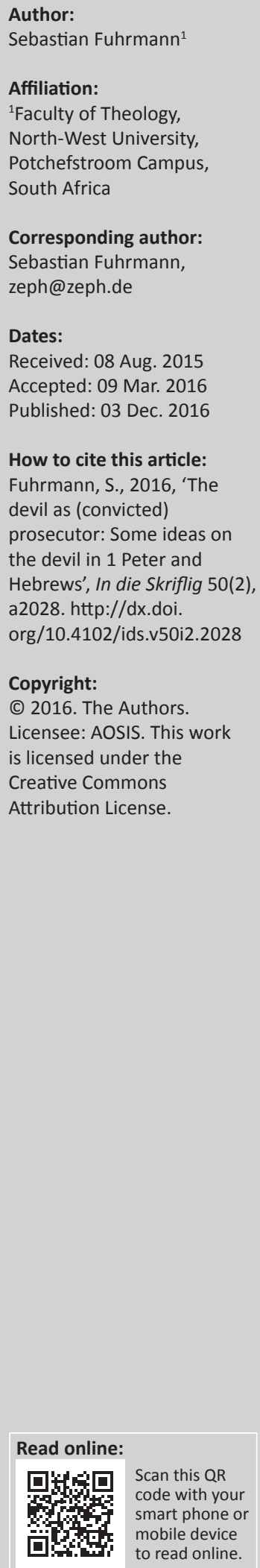

\begin{abstract}
The article suggests that the relationship between Christ's death and the defeat of the devil (Heb 2:14), as well as the metaphor of the devil as an adversary prowling like a roaring lion (1 Pt 5:8) possibly share the same background - i.e., the ancient Roman judicial phenomenon of crimen calumniae. This legal practice was established to stop prosecutors from bringing forward false charges. Convicted calumniators were removed from office and suffered additional punishments. This background might help explain the fact that the devil was defeated according to Hebrews by way of false accusation, and that the devil in 1 Peter does not attack the believers, but is only on the prowl for justified accusations.
\end{abstract}

\section{Introduction}

The devil is mentioned only one time in 1 Peter and Hebrews (1 Pt 5:8; Heb 2:14), and in both instances the precise frame of reference is rather obscure. This obscurity is not exclusively limited to these two writings. In general, it is a complex issue to define what or who the New Testament authors meant when they referred to Satan or the devil (see the discussion in Johnson 1999:145-146). The New Testament's mention of Satan does not make it possible to sketch a unified picture of the figure the texts describe, or even to develop the ideas that underlie that figure. Ultimately, there are two main tendencies: Satan/devil is understood either as an accuser or as the embodiment of opposition to God. To completely develop these traditions in detail, however, would require more space than available in this Festschrift. Therefore, simply put, as an accuser, Satan/devil is in a position against God, but belongs, nevertheless, to the heavenly court and the divine realm. He is a tempter or accuser, as most prominent in the book of Job (Job 1-2; cf. Achtemeier 1996:340-341; but see also Zch 3; or the synoptic stories of Jesus' temptation), but not the personification of opposition to God. The idea of Satan/devil as the embodiment of opposition to God appears however, in more strongly dualistic contexts, for example in the Johannine corpus or in apocalyptic literature (e.g. Sapientia Salomonis 2:23-24; Vita Adae et Evae 11:2-17:3 [esp. 12:1-2] and Slavonic Enoch 31). Such contexts depict the prince of the world as opposed to God and the world ruled by him as godless, corrupt, and evil. The dividing lines between these two tendencies, however, are not always clear. Thus the author of Revelation (Johannine), for example, can speak of the devil as 'the accuser ( $\dot{o} \kappa \tau \tau \dot{\gamma} \gamma \omega \rho$ ) of our brothers, who accuses them in front of our God day and night' (Rv 12:10), a typical Joban picture of Satan/devil.

For 1 Peter and Hebrews, the image of the devil (both texts speak only of $\delta$ iá $\beta 0 \lambda \mathrm{o} \varsigma$ ) is associated rather with an accuser, even if the two texts only offer a partial view of their conception of the devil. What follows will potentially lay the tradition-historical foundation for the references to the devil in these two texts and add a piece to the mosaic of early Christian ideas in the late 1st and early 2nd centuries. The article argues that the defeat or disempowerment of the devil has a connection to the original function of Satan as an accuser in the heavenly court and to crimen calumniae and its punishment in Roman law. ${ }^{1}$

\section{The devil in 1 Peter}

Despite or due to the obscurity of the texts available, there are not many studies that deal with the topic of the devil. For 1 Peter, according to Brown's (2011) history of research, only one study (Paschke 2006) had been published by 2011; in 2013 two more followed, viz. Charles and Martin. Martin's (2013) and Paschke's (2006) works focused on the metaphor describing the devil as a

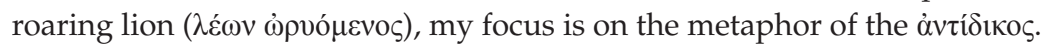

\footnotetext{
1.A footnote cannot express my gratitude for the extraordinary time I was able to spend with Fika Janse van Rensburg in Potchefstroom
} I got to know and work with someone truly admirable. Ad multos annos. 
At the end of 1 Peter, after the exhortations to the elders and believers, and before the doxology (1 Pt 5:10-11) and the postscript, the author refers to the devil in 1 Peter 5:8-9:

Discipline yourselves, keep alert. Like a roaring lion your

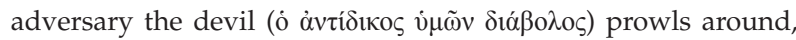
looking for someone to devour. Resist him, steadfast in your faith, for you know that your brothers and sisters in all the world are undergoing the same kinds of suffering. (NRSV)

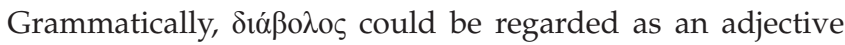

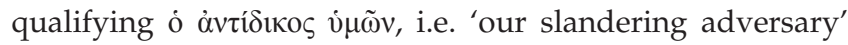
(cf. Charles 2013:409-410), or as a noun in apposition to ó

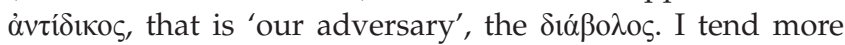
toward the second interpretation. In support for the latter, $\mathrm{P}^{72}$ offers a varia lectionis which adds the definite article, that is $\dot{0}$ $\delta i \alpha ́ \beta 0 \lambda o{ }^{\prime}$, suggesting that the text was already understood according to the second interpretation quite early on.

This combination of $\alpha v \tau i \delta$ เ New Testament, and only once attested in extra-biblical literature (Vita Adae et Evae, § 33: adversarius diabolus; the

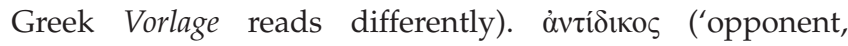
adversary in a suit', cf. Liddell Scott \& Jones 1940) evoke connotations that are related to a prosecutor or accuser at a

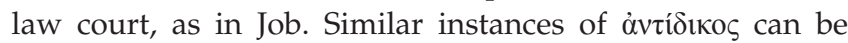
found in Matthew 5:25, Luke 12:58 and 18:3 (cf. Pr 18:17, which refers to the idea of an accuser in a court).

With Charles (2013:411), one can say that the temptation in 1 Peter is to abandon Christ and thus also the community, by returning to pagan attitudes. This temptation comes from the pagan environment, which has marginalised the community. The world itself, however, is not identified with the evil one, the devil, as it is in Revelation (18:11-14, 24; cf. DeVilliers 2013:39) with reference to the Roman Empire. Rather the author of 1 Peter calls believers to subject themselves to Roman rule (1 Pt 2:13). One can hardly say that the nonChristian world is actively threatening or tempting the Christian community; rather it constitutes a threat only passively. As a part of this menacing outside world, the $\delta$ ió $\beta$ o $\lambda_{0} \varsigma$ is, as the author of 1 Peter explains, a roaring lion, prowling around, waiting for a believer to abandon the protected realm of the community of discipleship in order to devour her or him. The depiction of the devil in 1 Peter has perhaps its closest parallels in 1 Timothy. In the passage listing the qualifications for bishops, 1 Timothy 3:6 warns of

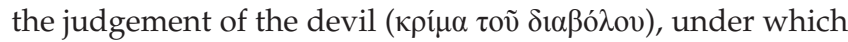
those who are 'puffed up with conceit' will fall. First Timothy

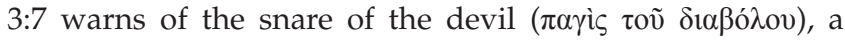
metaphor similar to the roaring lion, which brings to life the image of hostile surroundings outside the protected borders of the community and the risks of finding oneself outside those borders.

The point is that the devil waits for a justified claim on a fallen believer; he obviously wants - and, as will be shown, needs -

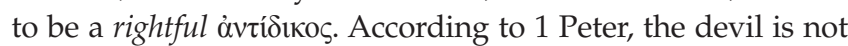
evil in the sense that he does bad to the community of believers, but is rather to be understood as a prosecutor who seeks a justified claim against his opponent. For this reason, the power to resist the devil lies not in resisting his temptations - which may be a hard task, since the devil might disguise himself, et cetera - but in maintaining sobriety, vigilance, and faith (1 Pt 5:8-9; cf. Charles 2013:414). That is, the principles of fear and obedience are the appropriate means required to withstand the devil.

\section{The devil in Hebrews}

Like 1 Peter, Hebrews mentions the devil only once, in a seemingly disconnected statement in 2:14-15:

Since, therefore, the children share flesh and blood, he [i.e. Christ] himself likewise shared the same things, so that through death

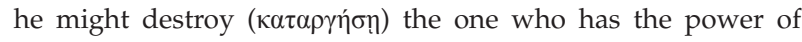
death, that is, the devil, and free those who all their lives were held in slavery by the fear of death. (NRSV)

In Hebrews the devil appears as defeated, although the translation of the NRSV might draw too optimistic a picture: $\kappa \alpha \tau \alpha \rho \gamma \varepsilon \dot{\omega} \omega$ means to remove someone's power rather than to destroy it (cf. Feneberg 1991). The devil remains alive, though not in a position to exercise influence on the believers.

The motif of the disempowerment or even of the destruction

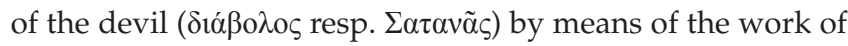
Christ occurs relatively often in the New Testament (Mt 25:41; Lk 10:18; 1 Jn 3:8; Rv 12:9-12; 20:2, 10). Interestingly enough, there is noexplicit description of the disempowerment process or the exact connection between the work of Christ (incarnation and death, as in Heb 2:14) and the disempowerment of the devil. Although there are descriptions of the results - an 'eternal fire [is] prepared for the devil and his angels' (Mt 25:41); Satan 'fell from heaven like a flash of lightning' (Lk 10:18); or he 'was thrown down to the earth' ( $\operatorname{Rv} 12: 9)$ - Scripture is silent as to how the devil is actually defeated (most commentators ignore this gap; but see Braun 1984:65: 'Wie die Entmachtung des Teufels durch Jesu Tod vor sich geht, sagt der $\mathrm{Hb}$ nicht explizit.' Braun then offers some solutions, relying anachronistically, however, on later Gnostic material).

In Hebrews the devil is qualified as the one who 'has the power of death', an idea that possibly is connected to the thought of death as the wages of $\sin (\mathrm{Rm} 6: 23)$, that is in the sense of a just (and fitting) punishment.

Thus 1 Peter 5:8-9 and Hebrews 2:14-15, among others, do not identify the devil with the evil world as such. Rather, the devil is a of member of a legal system - explicitly in 1 Peter

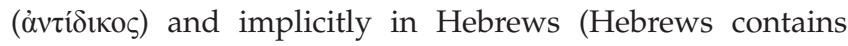
several allusions to the divine law court, where Christ emerges as the advocate - in particular Heb 7:25; cf. Ellingworth \& Nida 1983:157-58; and Fuhrmann 2006: passim). Why then would the devil be afraid to accuse those members of the community who obey God's commandments (1 Pt) and why is the devil disempowered by Jesus' death (Hebrews)? 


\section{A possible background: The crimen calumniae}

In the Roman legal system there were no state prosecutors. As a rule, trials were undertaken by private individuals and consisted of a plaintiff, a defendant, and a judicial authority. In Roman provinces, local authorities served as judicial authorities (cf. Williams 2012:142; e.g., Ac 16:19-24 for Philippi; Ac 17:5-19 for Thessalonica). Accusations were brought forth by private individuals rather than by the state, and accusers faced the accused in an official hearing (cf. Pliny, Epistula 10.97; Tertullian, Ad Scapulam 4.3). To issue a charge, the first step taken was the iurisdictio (e.g. Harris 2007), in which the litigant petitions the governor to grant a hearing (cf. Williams 2012:170), which could be refused (e.g. as with Gallio in Ac 18:12-17) or accepted. Then the governor hears the case using the process of cognitio [investigation], or assigns judges. The former, however, was probably the more usual way, at least at the end of the 1st century CE (Sherwin-White 1963:13-23; Williams 2012:172 n. 114). On the day of the conventus, the plaintiff hands over a libellus at the governor's court, registering the details of the charges, the names of both the accused and the accuser, and his or her own signature (a formal subscriptio or inscriptio). The libellus was introduced 'for the purpose of preventing anyone from rashly denouncing another, when he [the accuser] knows that his accusation, if false, will not go unpunished' (Scott 1932:11: Digestes 48.2.7).

This provision became necessary because the system was apparently quite prone to various forms of abuse. Thus, in addition to the institution of the libellus, the Romans instituted three procedural offenses to deter would-be accusers: calumnia [making false accusations, whether out of malice or frivolity, with little regard for the truth], praevaricatio [conspiring with the defendant to conceal the truth], and tergiversatio [failure to carry out the prosecution of a formally laid accusation]. Of these, the crimen calumniae is the most relevant procedural offense in relation to the devil in 1 Peter and Hebrews.

The oldest sources bearing witness to the punishment of a

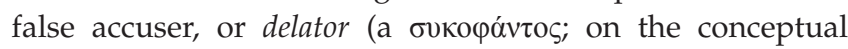

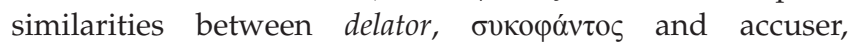
cf. Robinson 2007) are probably to be found in Egyptian papyri from Ptolemaic times (see the evidence provided by Taubenschlag 1916:70-71; cf. also Gaius [1946], Institutiones 4.174-175). Accordingly, the plaintiff had to pay 10 per cent of the damages sought if his case was dismissed. The underlying reason for this was the need to prevent the filing of insufficiently supported cases or ones that were completely false. Fines for such crimes could cost significantly more, however. This is evident in Luke 19:8 where Zacchaeus promises to pay four times the poena calumniae for false or malicious accusations, probably in the context of tax

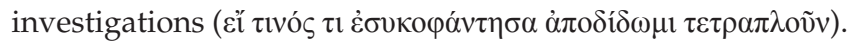
Among the evidence for the punishment of calumny in Greek texts there is the Edict of Tiberius Julius Alexander (ca. 68 BCE [OGIS 669]; text and commentary in White \& Oliver 1938:23-45).
In this document, the prefect gives instructions regarding

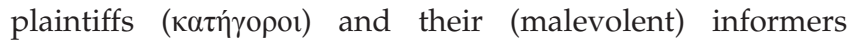


new plaintiff for a case that had already been dismissed, it was also illegal for a plaintiff to bring forth a case after he had already failed to present decisive evidence in three previous cases. As a sentence, half of the plaintiff's property would be

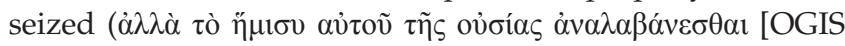
669, lines 42-43]; cf. also Lewis 1955-1956:120-125).

The earliest Latin evidence is from the Republican period. The iusiurandum calumniae is briefly mentioned in the lex repetundarum Tabulae Bembinae (line 19, FIRA $1^{2} .89$ s.; cf. Centola 1999:11-15). The actual crimen appears to have first been recorded in the lex Remmia (1st century BCE; for discussion see Centola 1999:19-24), since Cicero (107-44 BCE) mentions it in his speech For Sextus Roscius of Ameria 19.55 (Cicero 1903). Cicero refers to this law when he accuses the plaintiff Erucius of filing suit only for reasons of profit and of failing to observe the lex Remmia. Apparently, the law prescribed corresponding sentences, but it is not known when the law came into effect, nor what sanctions it set forth. In the following speech, Cicero (1903) offers further evidence as to the punishment for false accusations:

[I]f you act in such a way as to accuse a man ... without being able to say why or how ... I know these judges well, they will so firmly affix to your head that letter to which you are so hostile that you hate all the Calends too (litteram illam, cui vos usque eo inimici estis, ut etiam Kal<endas> omnis oderitis), that you shall hereafter be able to accuse no one but your own fortunes.

Supposedly, the penalty for calumny included the branding of the letter $K$ (according to the earlier spelling of calumnia) onto the accuser's forehead. This also meant that the accuser could never again file a suit with the court (cf. Centola 1999:41-60). Scholars have rightly doubted whether this sentence was ever actually put to effect (Levy 1933:154-155 calls it a legend). The sentence is better understood as a symbol (Robinson 2007:213: 'almost certainly metaphorical') demonstrating the fact that the accuser had, in fact, forfeited his civil right and was no longer permitted to engage in litigation (cf. Cicero 1903, 20:57: neminem alium nisi fortunas vestras accusare possitis). The sentencing was also made public (Digestes 23.43.11; cf. Mommsen 1899:490).

The Senatus consultum Turpillianum of 61 ce (cf. Marcian's [early 3rd century CE] comment in Digestes 48.16.1-5), also related to the lex Remmia, became a foundation for the commentary in the Digestes. S.c. Turpillianum debates the crimes of plaintiffs, such as calumny, collusion, and evasion (aut enim calumniantur aut praevaricantur aut tergiversantur; 48.16.1), where calumny consists in bringing forth a false accusation (ibid.: calumnari est falso crimina intendere; cf. Mommsen 1899:492).

Not every false accusation was considered to and punished as calumny. The court had to decide whether there was malicious intent. Someone once convicted of calumny, however, could not escape penalty even when the case was dropped 
(cf. Digestes 48.1.10: not appearing before the court could also be considered calumny). If a plaintiff was found guilty of calumny, various penalties could be put in place: the payment of 5 pounds of gold (Digestes, 47.15.3.3 [Macer]); the loss of the right to file further suits (except in cases where one is the wronged party; Digestes 47.15.5. [Venuleius Saturninus]; Digestes 48.2.4 [Ulpian]); the expulsion from the Senate or local council (Digestes 50.2.6.3. [Papinian]; Sententiae Pauli 5.4.11: omnes enim calumniatores exilii vel insulae relegatione aut ordinis amissione puniri placuit ['all calumniators shall be punished by exile, by relegation to an island, or by the loss of their rank'] Scott 1932:5); loss of certain civil rights (Digestes 3.2.1; Mommsen 1899:494) like the right to serve in the military (Digestes 3.2.4.4 [Ulpian]); or even exile (Tacitus, Annales, 14.41; cf. Harris 2007:22; Sententiae Pauli 5.4.11, see above).

Beyond the juridical commentaries mentioned above, there is both pagan and Christian literature, which offers further evidence for calumnia and the punishment of delatores, бокофи́vто, and calumniatores (Justin Martyr, 1 Apology 68 [Eusebius, Historia ecclesiastica 4.9]; Tacitus, Annales 13.33 passim; Dio Cassius, Historia 66.19; 68.1; Historia Augusta: Vita Commodi 7; 18.15; 19.7; Vita Didii Juliani 2; Vita Pertinacis 7.1; 9.10; Vita Severi 4.3; Vita Alexandri 45.6, etc.). The ammount of evidence suggests that the phenomenon of bringing forward false charges was a generally well-known phenomenon in the 1 st and 2 nd centuries CE.

In subsequent periods (particularly in the time after Constantine, i.e. the late 4 th and early 5th centuries CE) sentences for such crimes became even severer, rising even to the level of lex talionis. That is, a plaintiff convicted of bringing forth a false or unsubstantiated case would have to pay the penalty he demanded of the defendant had he won the case (cf. Mommsen 1899:496; Petschow 1973, who refers also to Dt 19:16 e.f. and Sus $\theta$ ' alongside other ancient Near Eastern evidence).

\section{Conclusion}

The devil of 1 Peter, prowling around like a lion, is waiting for the opportunity to bring forth a substantiated claim, because he fears the punishment if he is convicted as a calumniator. 1 Peter does not develop this idea, nor does the author of Hebrews. However, there must be some tradition underlying the brief mention of the devil's disempowerment in Hebrews, otherwise the statement would have had to have further explanation. Jesus' death possibly serves as the enforcement of a sentence demanded by the devil as accuser (and ruler over death). This sentence could be based on the conceptual link between sin and death as its penalty found in Romans 6:23. Christ, as the son of God, voluntarily shared in humanity and lowered himself to a level below the angels because of the devil's

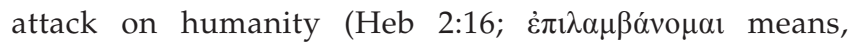
according to Liddell et al. [1940], to seize, or to attack; Heb 2:16 is no exception, pace most translations and New Testament Greek lexicons; cf. Fuhrmann 2006; 2010:92-93). The devil attacks, accuses and successfully prosecutes
Jesus for the death penalty. Since Hebrews explicitly describes Christ as sinless, and thus inculpable (Heb 4:15), the devil as accuser is convicted of making a false accusation, i.e. calumny. Thus, he no longer has the right to remain an accuser in the heavenly court and has, as a result, been stripped of his power.

\section{Acknowledgements Competing interests}

The author declares that he has no financial or personal relationships which may have inappropriately influenced him in writing this article.

\section{References}

Achtemeier, P.J., 1996, 1 Peter: A commentary on first Peter, Fortress, Minneapolis, $\mathrm{MN}$.

Braun, H., 1984, An die Hebräer, Mohr Siebeck, Tübingen.

Brown, D.R., 2011, 'The devil in the details: A survey of research on Satan in biblical studies', Currents in Biblical Research 9, 200-227.

Centola, D.A. (ed.), 1999, II crimen calumniae: Contributo allo studio del processo criminale romano, Scientifica, Naples.

Charles, D., 2013, 'Votre adversaire le diable rôde comme un lion rugissant (1P 5, 8)', Revue Biblique 120(3), 405-422.

Cicero, M.T., 1903, The Orations, transl. C.D. Yonge, George Bell \& Sons, London, viewed 20 April 2016, from www.perseus.tufts.edu

DeVilliers, P.G., 2013, 'Entering the corridors of power: State and church in the reception history of revelation', Acta theologica 33(2), 37-56.

Ellingworth, P. \& Nida, E.A., 1983, A translator's handbook on the letter to the Hebrews, United Bible Societies, London.

Feneberg, W., 1991 “"Vernichten” oder "Entmachten": Bemerkungen zu dem

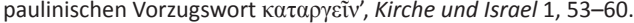

Fuhrmann, S., 2006, Vergeben und Vergessen: Christologie und Neuer Bund im Hebräerbrief, Neukirchner, Neukirchen-Vluyn.

Fuhrmann, S., 2010, 'The Son, the angels, and the odd: Psalm 8 in Hebrews 1 and 2', in D.J. Human \& G.J. Steyn (eds.), Psalms and Hebrews: Studies in reception, pp. 83-98, T \& T Clark, London.

Gaius, 1946, The Institutes of Gaius: Text with critical notes and translation, ed. F. de Zulueta, Clarendon, Oxford.

Harris, J., 2007, Law and crime in the Roman world, Cambridge University Press, Cambridge.

Johnson, L.A, 1999, 'Satan talk in Corinth: The rhetoric of conflict', Biblical Theology Bulletin 29(4), 145-155.

Levy, E., 1933, 'Von den römischen Anklägervergehen', Zeitschrift für Rechtsgeschichte, Römische Abteilung 53, 151-233.

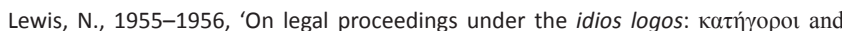
бטкофи́vचai', Journal of Juristic Papyrology 9-10, 117-125.

Liddell, H.G., Scott, R. \& Jones, H.S., 1940, A Greek-English lexicon, Oxford University Press, Oxford.

Martin, T.W., 2013, 'Roaring lions among diaspora metaphors: First Peter 5:8 in its metaphorical context', in D. du Toit (ed.), Bedrängnis und Identität: Studien zu Situation, Kommunikation und Theologie des 1. Petrusbriefes, pp. 167-182, De Gruyter, Berlin.

Mommsen, Th., 1899, Römisches Strafrecht, Duncker \& Humblodt, Leipzig.

Paschke, B.A., 2006, 'The Roman ad bestias execution as a possible historical background for 1 Peter 5.8', Journal for the Study of the New Testament 28(4), 489-500

Petschow, H., 1973, 'Altorientalische Parallelen zur spätrömischen Calumnia', Zeitschrift für Rechtsgeschichte, Römische Abteilung 90, 14-35.

Robinson, O.F., 2007, 'The role of delators', in J.W. Cairns \& P.J. du Plessis (eds.), Beyond dogmatics: law and society in the Roman world, pp. 206-220, Edinburgh University Press, Edinburgh.

Scott, S.P. (ed. \& trans.), 1932, The Civil Law, The Central Trust Company, Cincinnati, viewed 20 April 2016, from www.constitution.org/sps/sps.htm

Sherwin-White, A.N., 1963, Roman society and Roman law in the New Testament, Clarendon, Oxford.

Taubenschlag, R., 1916, Das Strafrecht im Rechte der Papyri, Teubner, Leipzig.

White, E.H.G. \& Oliver, J.H., 1938, The temple of Hibi in El Khārgeh Oasis, pt. 2: Greek Inscriptions, The Metropolitan Museum of Art Egyptian Expedition, New York.

Williams, T.B., 2012, Persecution in 1 Peter: Differentiating and contextualizing early Christian suffering, Brill, Leiden. 